\title{
New Discovery and Significance of Microbialites of the Middle Ordovician Majiagou Formation in Liujiang Basin, Hebei, China
}

\author{
Qingchun Wang ${ }^{1,2,3}$, Ping $\mathrm{He}^{1,3,4}$, Fangle Shen ${ }^{5}$, Jiangmin $\mathrm{Du}^{1,3}$ \\ ${ }^{1}$ School of Geosciences, Hebei GEO University, Shijiazhuang, China \\ ${ }^{2}$ Shandong Key Laboratory of Depositional Mineralization \& Sedimentary Mineral, Qingdao, China \\ ${ }^{3}$ Hebei Key Laboratory of Strategic Critical Mineral Resources, Hebei GEO University, Shijiazhuang, China \\ ${ }^{4}$ School of Geosciences, Yangtze University, Wuhan, China \\ ${ }^{5}$ College of Huaxin, Hebei GEO University, Shijiazhuang, China
}

Email address:

wangqingchun@sina.com (Qingchun Wang), heping1114@sina.com (Ping He), fangleshen@163.com (Fangle Shen), Jiangmindu@163.com (Jiangmin Du)

\section{To cite this article:}

Qingchun Wang, Ping He, Fangle Shen, Jiangmin Du. New Discovery and Significance of Microbialites of the Middle Ordovician Majiagou Formation in Liujiang Basin, Hebei, China. Earth Sciences. Vol. 10, No. 4, 2021, pp. 189-197. doi: 10.11648/j.earth.20211004.16

Received: July 23, 2021; Accepted: August 24, 2021; Published: August 31, 2021

\begin{abstract}
The concept, classification, genesis, and significance of microbialites have been constantly improving for over a century, but they are still hot spots in the field of geology because of the strong attractions and many unsolved mysteries such as the mechanism of the microbial deposition process, the microbial induced sedimentary structures, and so on. At the same time doubt and confusion arises among students and beginners because of the mysteries. Generally, any findings of various stromatolites, oncolites, and thrombolites are all classified under microbialites. Moreover, microbialites have also been discovered from the middle Ordovician Majiagou formation in Liujiang Basin, Hebei, China. As an important geological practice base for thousands of students and beginners every year, in order to enhance the interest in geosciences the further research of the microbialites found in Liujiang Basin is necessary. In this study, the classification scheme of microbialites has been summarized. On this basis, the study shows that the main microbialites in the study area are microbial carbonate rocks, which include wavy, columnar, conical-shaped stromatolite carbonate rocks and oncolite carbonate rocks. The variety, macroscopic characteristics, and clear internal features of microbialite carbonate rocks are all have considerable significance in judging hydrodynamic conditions, sedimentary environment, paleogeographic characteristics, and biological evolution. And the evolutionary process of different kinds of microbialites has been discussed. However, the roles of microbialites in the formation mechanism and ecological significance are still need further study. With the new discovery of microbialites from the middle Ordovician Majiagou formation in Liujiang Basin, a new window of study microbialites has been opened for everyone. More findings and detailed characteristics of microbialites in this area are urgently needed during geological practice.
\end{abstract}

Keywords: Microbialite, Stromatolite, Oncolite, Majiagou Formation, Liujiang Basin

\section{Introduction}

Microbial rocks have been studied by geologists for more than one hundred years. Microbial rocks research started with stromatolite, a term proposed by Kalkowsky [1]. Thrombolite, another important type of microbial rock, was defined by Aitken [2]. Then, the term oncolite was defined by Flügel et al in 1982 [3]. However, the term microbialite was only formally proposed by Burne and Moore [4]. Since then, an increasing number of geologists have become interested in the concept, genesis, classification, significance, and other characteristics of microbialites. In order to catch attention and to guide the geological practice, on the basis of detailed study of the new microbiolites discoveries from the middle Ordovician Majiagou formation in Liujiang Basin, the classification and concepts of microbiolites were summarized and improved. 
The rapid progress and improvement in the terminology and classification of microbialites are due to the increase in research. Burne and Moore described microbial rocks initially as "carbonate deposits mainly formed by benthic microbial communities". In recent years, the term microbialite mainly refers to sediments or sedimentary rocks formed in situ by capturing and binding debris sediments from benthic microbial communities or by inorganic or organic-induced mineralization associated with microbial activities [5-10]. The main components of microbialites are carbonate rocks, phosphorite, siliceous rocks, ferruginous rocks, manganic rocks, and organic shales; however, microbialites can also consist of sulfide, clay rocks, and various clastic rocks [11]; microbial carbonate rocks are the most common among these components [12]. For the classification of microbial rocks, Burne and Moore classified them initially into five types, namely, stromatolites, thrombolites, oncolites, mini-structured microbial rocks, and spherical-structured microbial rocks. Further study on the classification was also conducted by Riding [13-14]. In 2018, a new classification scheme for microbialites (Table 1) was published [10]. To date, the term microbialites are described as "sedimentary bodies mainly formed by microbial processes or mainly composed of microbial skeletons, including stromatolites, laminated stone, oncolites, thrombolites, homogeneous stone, molding rocks, microbial skeleton rocks, microbial cohesive rocks, microbial grainstone, and microbial packstone".

Table 1. New classification scheme of microbialites (according to [10])

\begin{tabular}{|c|c|c|c|c|}
\hline \multicolumn{2}{|c|}{ Classification basis } & \multicolumn{2}{|l|}{ Types } & Characteristics \\
\hline \multirow{6}{*}{$\begin{array}{l}\text { No-calcified } \\
\text { microorganism }\end{array}$} & \multirow{5}{*}{ Benthic } & Stromatolite & & Columnar/mound-shaped, interior with biological lamina structure \\
\hline & & Laminated stone & & Bedded-shaped, with biological lamina structure \\
\hline & & Oncolite & & Nodular-shaped, interior with biological concentric laminae \\
\hline & & Thrombolite & & Moundy/columnar/bedded-shaped, interior with coagulated structure \\
\hline & & Homogeneous stone & & Moundy/columnar/bedded-shaped, biogenic micrite sediments \\
\hline & Plankton/Float & Molding rock & & More than $50 \%$ of the rock are biological molding fossil \\
\hline \multirow{4}{*}{$\begin{array}{l}\text { Mineralized } \\
\text { microorganism }\end{array}$} & Benthic & Microbial skeleton rock & & The skeleton of the rock is formed by calcified organisms \\
\hline & \multirow{3}{*}{ Plankton/Float } & Microbial grainstone / & Radiolaria & Radiolaria with contacted skeleton \\
\hline & & packstone & Globigerina & Globigerina with contacted skeleton \\
\hline & & Diatomite & & Diatomite with contacted skeleton \\
\hline
\end{tabular}

Mcrobialites has become a geological research hotspot given the complex formation process and the interaction products between microbial communities and the environment [15-22]. The ecological and environmental significance and the favorable characteristics for the formation and accumulation of energy minerals considering its high organic content and good reservoir space are the reasons for the increasing interest for microbialites [23]. In comparison with the Precambrian era, the outburst of higher organisms in the Phanerozoic era resulted in higher consumption of microorganisms and bacteria at the bottom of the biological chain. The development of microbialites seemed inhibited. Nevertheless, a substantial amount of microbialites develop when severe-extreme environments and/or biotic extinction events occur [24-27]. Some microorganisms with rapid reproduction abilities and high adaptability to hostile conditions may be the major contributors to microbialite proliferation [28-30].

In recent years, many types of microbialites that developed in the middle Ordovician strata have been under observation by the authors of the present work; these data contribute to the teachings and research on Liujiang Basin, which is located in the Northeastern Hebei province of China. The macroscopic characteristics and geological significance of the microbialites have been preliminarily investigated in the subsequent section. The relevant of the sedimentary environment, rocks, microbialites, and their evolution have been discussed briefly. It is hoped that the new discovery and view of this paper will advance the study of microbiolites.

\section{Geological Characteristics}

\subsection{Regional Tectonic Characteristics}

Liujiang Basin is located approximately $25 \mathrm{~km}$ north of Qinhuangdao in the Northeastern Hebei Province. In terms of tectonic settings, Liujiang Basin lies in the Shanhaiguan platform-arching district (III5) [31-32], which is called tectonic unit-III in the Eastern Yanshan platform fold belt of North China. The geological evolution process of Liujiang Basin is basically consistent with that of the North China platform. The complex processes include the crystalline basement formation period in the Archean-early Proterozoic era, the relatively stable caprock formation period in the Mesoproterozoic-Mesozoic era, the fold intrusion activity period in the Indosinian-Yanshanian era, and the strong differential uplift activity period in the Himalayas [32]. Liujiang Basin is also known as Liujiang syncline (Figure 1). The syncline is situated within the jurisdiction of the Shimenzhai town with a steep west wing and a gentle east wing. This area spans approximately $20 \mathrm{~km}$ long from Chengziyu in the north to Shilongshan and Nanlinzi in the south. The width is nearly $8 \mathrm{~km}$ from Wawayu and Zhangyanzi in the east to Wuzhuang and Shanyangzhai in the west. The morphological characteristics of Liujiang syncline are mainly formed by the strata of the Neoproterozoic-Mesozoic era. The core of the syncline is mainly composed of Permian and Jurassic stratum, which mostly covers Jurassic volcanic rocks. The both flank of the 
syncline are mainly Cambrian, Ordovician and Carboniferous rocks (Figure 1).

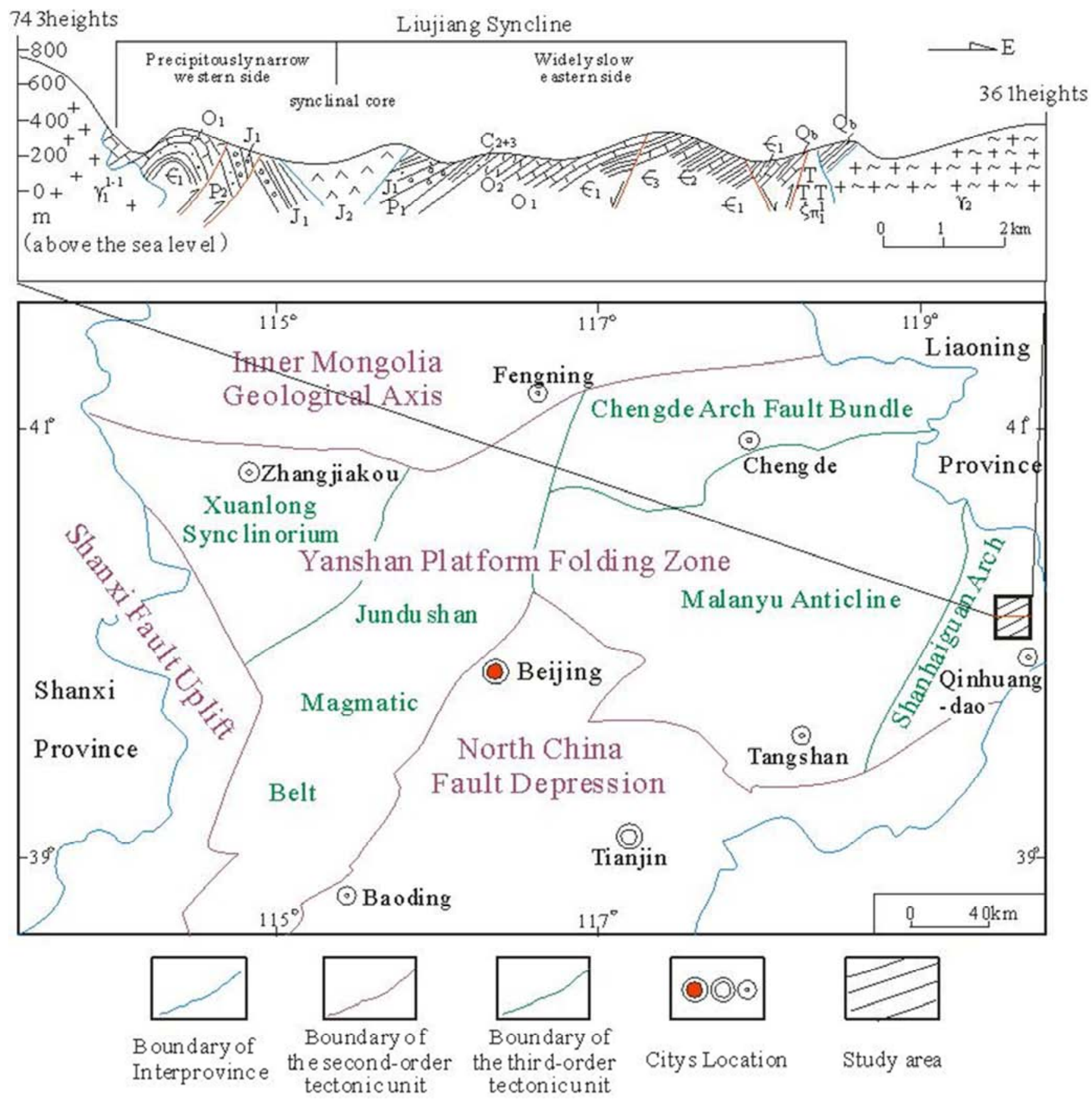

Figure 1. Tectonic location and profile sketch map of Liujiang Basin (according to Liu CZ and Ma FR 2016; Wang QC et al. 2016).

\subsection{Straticraphic Characteristics}

Previous studies have demonstrated that the Ordovician rocks in Liujiang Basin are mainly composed of the middle Ordovician Majiagou formation, the lower Ordovician Yeli formation, and the lower Ordovician Liangjiashan formation [33-35]. The three formations largely consist of carbonate deposits. The main sedimentary rocks of the Yeli formation include micrite limestone and gravel calcarenite limestone in middle-thick layers, and mud-strip limestone and calcareous shale in thin layers. The main sedimentary rocks of the Liangjiashan formation are leopard-like limestone and gravel calcarenite limestone in thick layers. The Majiagou formation is mostly banded chert dolomitic limestone, gravel calcarenite dolomitic limestone, lime dolostone, and fine-crystalline dolomite. The microbialites developed in the Cambrian strata of Liujiang Basin have been studied by previous geologists [36], but only a few of them have been mentioned in the Ordovician strata. The authors of this paper found that the microbialites developed in the mid-lower strata of the middle Ordovician Majiagou formation are predominantly composed of microbial carbonate rocks. The basic characteristics of the microbialite strata of the middle 
Ordovician Majiagou formation in Liujiang Basin are illustrated in Figure 2.

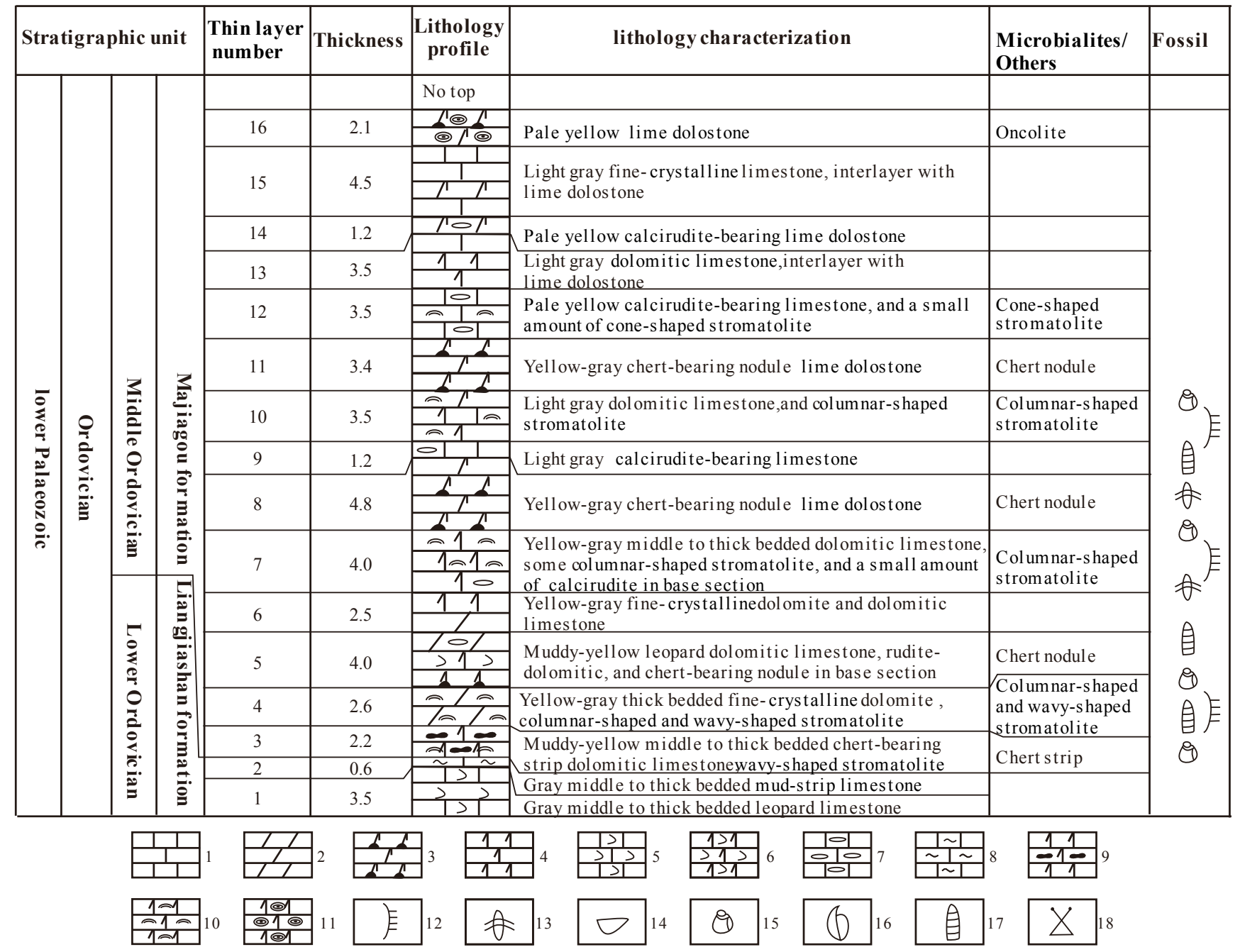

1-limestone; 2-dolomite; 3-chert-bearing nodule lime dolostone; 4-dolomitic limestone; 5-leopard limestone; 6-leopard dolomitic limestone; 7-calcirudite; 8-mud-strip limestone; 9-chert-bearing strip dolomitic limestone; 10- stromatolitic dolomitic limestone; 11-Oncolitic dolomitic limestone; 12-graptolite ; 13-trilobite; 14-ostracoda; 15-gastropod ; 16-brachiopod ; 17-cephalopod ; 18-sponge

Figure 2. Distribution sketch profile of middle Ordovician Majiagou formation microbialites in Liujiang Basin.

The microbialite stratigraphic profile of the middle Ordovician Majiagou formation in Liujiang Basin is the provenance of field exploration. This microbialite stratigraphic profile can basically reflect the vertical evolution characteristics of the stratum despite the slightly insufficient accuracy of this profile. The middle and lower parts of the Majiagou formation are mainly exhibited in the stratigraphic profile, which includes 16 single thin layers. Microbialites have five sections, namely, thin layer 3-4, thin layer 7 , thin layer 10 , thin layer 12 , and thin layer 16 . The main microbialites are stromatolite and oncolite carbonate rocks. The specific types are listed in Table 2.

Table 2. Types of middle Ordovician Majiagou formation microbialites in Liujiang Basin.

\begin{tabular}{|c|c|c|}
\hline Types of microbialites & Subtypes of microbialites & Rocks of microbialites \\
\hline \multirow{3}{*}{$\begin{array}{l}\text { Stromatolite carbonate } \\
\text { rocks }\end{array}$} & Wavy-shaped stromatolite carbonate rocks & $\begin{array}{l}\text { Wavy-shaped stromatolite dolomitic limestone;Wavy-shaped stromatolite } \\
\text { fine-crystalline dolomite }\end{array}$ \\
\hline & Columnar-shaped stromatolite carbonate rocks & $\begin{array}{l}\text { Columnar-shaped stromatolite fine-crystalline dolomite;Columnar-shaped } \\
\text { stromatolite dolomitic limestone }\end{array}$ \\
\hline & Cone-shaped stromatolite carbonate rocks & $\begin{array}{l}\text { Cone-shaped stromatolite limestone;Cone-shaped stromatolite dolomitic } \\
\text { limestone }\end{array}$ \\
\hline Oncolite carbonate rocks & $\begin{array}{l}\text { Symmetrical bedded framework oncolite } \\
\text { carbonate rocks }\end{array}$ & $\begin{array}{l}\text { Symmetrical bedded framework oncolite limestone;Symmetrical bedded } \\
\text { framework oncolite dolomitic limestone;Symmetrical bedded framework } \\
\text { oncolite siliceous dolomite }\end{array}$ \\
\hline
\end{tabular}




\section{Types and Macroscopic Characteristics of Microbialites}

\subsection{Stromatolite Carbonate Rocks}

As mentioned previously, the term "stromatolite" first appeared in 1908; however, as early as 1825, Steel had already reported calcareous sediments with a bedded framework (later called stromatolite) in the late Cambrian strata near Saratoga Springs, New York, USA. Thus, the research history of "stromatolite" had spanned more than 200 years. The terminology of stromatolites has been constantly improved with the development of research. On the basis of previous studies [36-40], the term "stromatolite" has been described in the present work as a "primary bedded biochemical sedimentary structure formed from mineral precipitation, sediment capture, and cementation through lifecycle activities of prokaryotes (cyanobacteria and photosynthetic bacteria), eukaryotic algae, and other microorganisms."

The micro-ecosystem of stromatolite is the "golden key" to studying its genesis. Simultaneously, stromatolite can also sensitively indicate the sedimentary environment and conditions of its growth period. Therefore, this term is regarded as the optimal "indicator" to studying its paleoenvironment and paleoclimate.

The characteristics of stromatolites include primary sedimentary structures, biogenic microstructures with bedded framework (alternating bright to dark or coagulation non-bedded framework), and the laminae with upward convex characteristics (typically shaped as columnar with different forms or stratiform sediments with laminae by clear boundaries); these characteristics can be used as important symbols for distinguishing stromatolites in the field. The macroscopic characteristics of different stromatolite types developed in the middle Ordovician Majiagou formation in Liujiang Basin are described in the following subsections.

\subsubsection{Wavy-shaped Stromatolite Rocks}

The wavy-shaped stromatolite carbonate rocks found in the middle Ordovician Majiagou formation of the Liujiang Basin are mainly developed in the bottom (3rd-4th thin layer) of the profile. The main rocks are chert-bearing wavy-shaped stromatolite dolomitic limestone and wavy-shaped stromatolite fine-crystalline dolomite. The weathering surface of the wavy-shaped stromatolite is pale gray-white. The framework of the stromatolite is easy to observe and identify from the weathering surface because the weathering resistance of bright and dark laminae is different. The single lamina is wavy and undulating. The thickness of a single lamina is only $1-5 \mathrm{~mm}$, but the thickness of the stratum can reach $15-45 \mathrm{~cm}$ by overlapping laminae (Figure 3 ). Incidentally, Armenoceras, Ophileta, and other biological fossils that have been retained rather completely, with clear structural characteristics, can be found in the stratum with stromatolite. Therefore, the low-energy hydrodynamic conditions of the formation environment can be inferred.

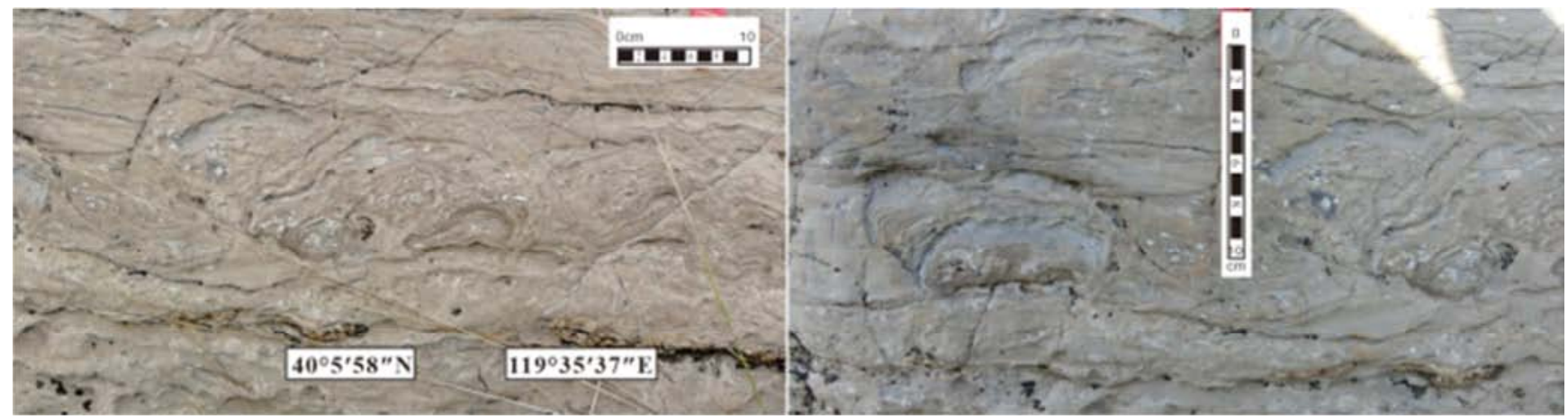

Figure 3. Wavy-shaped stromatolite carbonate rocks found in the middle Ordovician Majiagou formation in Liujiang Basin.

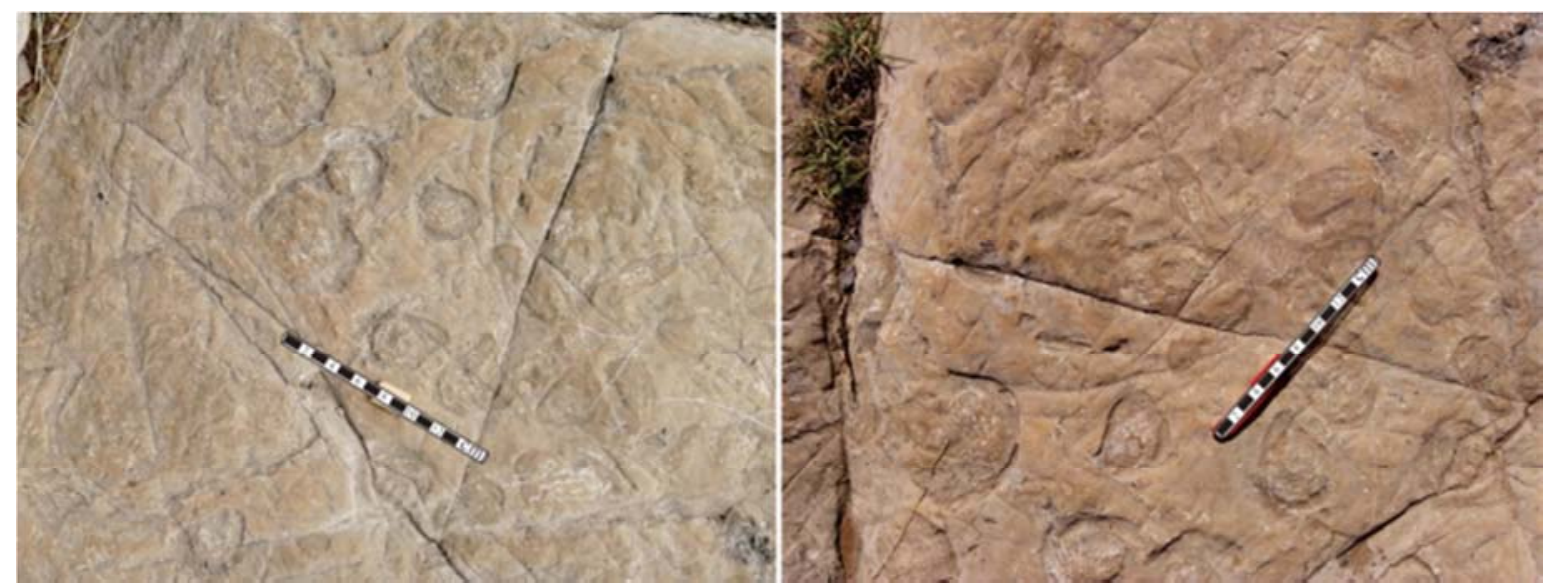

Figure 4. Columnar-shaped stromatolite carbonate rocks found in the middle Ordovician Majiagou formation in Liujiang Basin. 


\subsubsection{Columnar-shaped Stromatolite Rocks}

The columnar-shaped stromatolite carbonate rocks found in the middle Ordovician Majiagou formation in Liujiang Basin are mainly developed in the 4th, 7th and 10th thin layer of the profile. The main rock types are columnar-shaped stromatolite fine-crystalline dolomite and columnar-shaped stromatolite dolomitic limestone. The bright and dark laminae of the columnar stromatolites are discontinuous in the transverse direction but overlapping to columnar in the vertical direction. The thickness of a single lamina is mainly 1-3 mm, while the thickness of the stratum can generally reach 13-40 cm. The columnar-shaped stromatolites appear similar to concentric circles isolated from each other on the rock bed surface. The diameter of the circles is generally 3-6 $\mathrm{cm}$, and the maximum exceeds $10 \mathrm{~cm}$ (Figure 4). The low-energy hydrodynamic conditions can also be presumed given the complete retention of the biological fossils (such as Armenoceras and Ophileta) found in the 4th thin layer of the profile. The intraclasts and bioclasts in gravel in the 7 th and 10th thin layers indicate high-energy hydrodynamic conditions.

\subsubsection{Cone-shaped Stromatolite Rocks}

The cone-shaped stromatolite carbonate rocks found in the middle Ordovician Majiagou formation in Liujiang Basin are mainly developed in the 12th thin layer of the profile. Two types of cone-shaped stromatolite found in the study area are cone-shaped stromatolite limestone and cone-shaped stromatolite dolomitic limestone. The individual size of the cone-shaped stromatolite varies significantly (Figure 5). A large cone can reach $16 \mathrm{~cm}$ in height and $10 \mathrm{~cm}$ in diameter (Figure 5a). A small cone is only approximately $5 \mathrm{~cm}$ in height and $3 \mathrm{~cm}$ in diameter (Figure 5b). The whole cone-shaped stromatolites are inverted conical with bright and dark laminae. The diameter of the upward-raised lamina increases gradually from bottom to top. The outline of the cone individual is clear, with no scour and erosion marks. In the surrounding rocks of the cone-shaped stromatolite, well-rounded intraclasts and bioclasts, such as crinoid stems and gastropod debris, may also indicate high-energy hydrodynamic forming conditions.

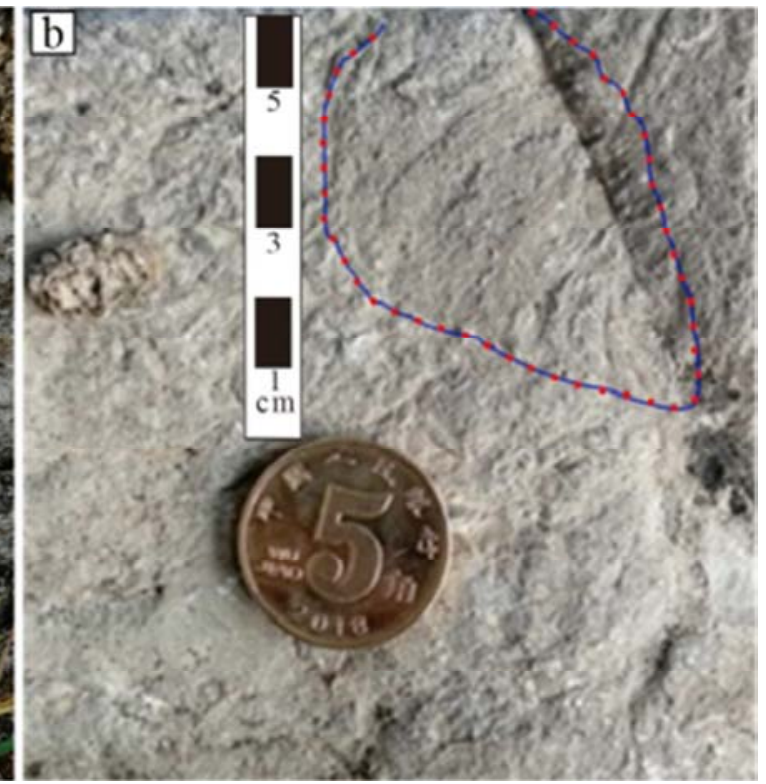

Figure 5. Cone-shaped stromatolite carbonate rocks found in the middle Ordovician Majiagou formation in Liujiang Basin.

\subsection{Oncolite Carbonate Rocks}

The term "oncolite" was developed and proposed by Flügel et al. in 1982. However, as early as 1916, Heim had already used this term to describe some coated grains in the Mesozoic strata of the Alps in Eastern Switzerland [41]. Oncolites are a kind of nonstationary growth lamellar concretions formed by mucous-secreting algae (bacteria) or microorganisms that capture and cohere fragmentary materials and calcium carbonate particles. Oncolites are composed of a core (nuclei) and a cortex (coating). The cortex will accumulate around the core during the growth of an oncolite [42-43]. Oncolites can develop in diverse environments during long geological periods. Since the
Precambrian era to the Quaternary era, oncolites have been reported extensively from continental facies to marine facies and from high- to low-energy hydrodynamic conditions. Oncolites can be used as an important indicator of regional stratigraphic classification and/or correlation and restoration of the paleogeographic environment $[6,44-46]$. What are the characteristics and significance of the oncolite in this paper?

The oncolite carbonate rocks found in the middle Ordovician Majiagou formation in Liujiang Basin are mainly developed in the 16th thin layer of the profile, whereas other scattered distributions are found in other thin layers. The main rocks are oncolite limestone, oncolite dolomitic limestone, and oncolite siliceous dolomite with symmetrical or semi-symmetrical bedded frameworks. The 
oncolitesconcentrated in the 16th thin layer have clear and visible symmetrical bedded individual frameworks (Figure 6a-b). Most of these oncolites are elliptical, with significantly different sizes. The small diameter is only a few millimeters, but the large diameters more than $30 \mathrm{~mm}$ (Figure 6a-b). Most oncolites with evenly developed bedded frameworks were poor sorted and good grinded, but some with little or no bedded characteristics (Figure 6c-d). The internal grains of oncolites are mainly micrite aggregates and fossil fragments with sparry calcite cements and little pyrite dark minerals. Therefore the sedimentary environment of the oncolite carbonate rocks developed in the 16th thin layer can be presumed to high-energy hydrodynamic conditions. The scattered oncolites in other thin layers are individually large and round-oblong in shape (Figure 6f). The clear symmetrical bedded framework and biological debris can be found in oncolites or the surrounding rocks. From there, the relatively high-energy forming conditions can also be speculated.
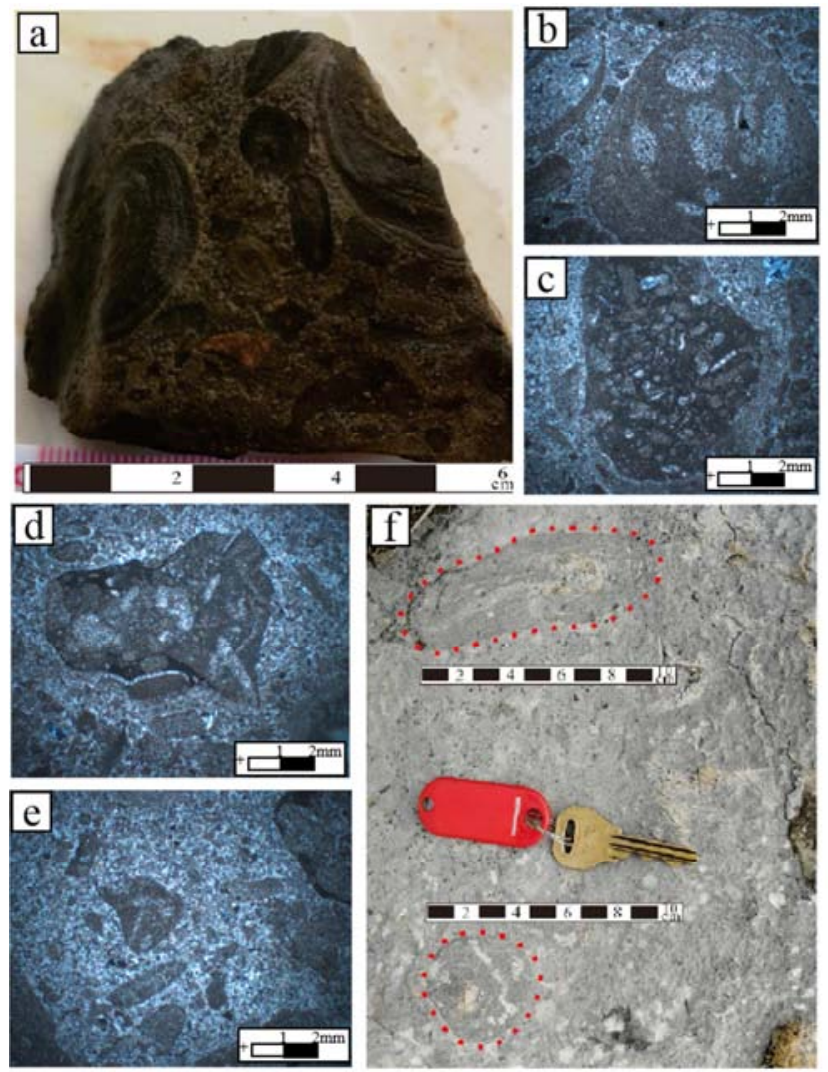

Figure 6. Oncolite carbonate rocks found in the middle Ordovician Majiagou formation in Liujiang Basin.

\subsection{Geological Significance of Microbialites}

As mentioned previously, microbialites are a research hotspot in the field of geology. Their complex forming process, the significance of ecological environment, the significance of energy and mineral resources, the significance of paleontological evolution, and the significance of sedimentary environment, attract researchers. The geological significance of microbialites is also attractive.

In general, microbialites are rich contents of organic matter.
Simultaneously, microbial carbonate rocks with favorable reservoir conditions are the most common rocks of microbialites. An improved reservoir space can capture metallogenic material or fluid minerals. Liujiang Basin can be used as a favorable research site for microbialites despite the lack of such typical kind of mineral resources in microbialites in this area.

The overlying strata of Majiagou formation in Liujiang Basin is the Benxi formation of Carboniferous rocks. Considerable strata have been lost, and a parallel unconformity contact surface has developed between them. The appearance of various microbialites in the Majiagou formation must be inevitably related to the tectonic movement and the evolution of the sedimentary environment. Further research in this area is necessary to understand the internal connection between the development of microbialites and the regional geological background.

From the bottom to upper member of Majiagou formation, the main sedimentary rocks are characterized by chert-bearing strip with relatively complete fossils, to bioclasts such as crinoid stems, calcarenite gravel, and fine-crystalline limestone and dolomite. The characteristics of different types of microbialites and their associated rocks can indicate the hydrodynamic variation of the forming environment. For example, the stromatolites in the study area have evolved from wavy to columnar and conical with the migration of geologic time. This process indicates that the hydrodynamic conditions are gradually enhanced, and the water environment has the trend of changing from the supra-tidal zone to the intertidal zone or channels in the sub-tidal zone. Therefore, the growth characteristics of microbialites in sedimentary environment analysis can be taken as an important reference for stratigraphic sequence and further study.

In addition, the extinction event near the end of Ordovician times is the first mass extinction in geological history. A large-scale glacial period was formed given the cold global climate at that time. Glaciers locked up water beds, and sea levels dropped. In addition, various invertebrates living in water disappeared in bulk, and approximately $85 \%$ of species became extinct. The microbialites mentioned in present work can provide some information during that time. Microorganisms, such as bacteria and algae, can survive in harsh environments given their strong adaptability. The reduction of the foraging consumption of microorganisms might be due to other organisms' extinction in large quantities; this phenomenon allowed the microorganisms to multiply. The microbialites could eventually develop if suitable preservation environments appear. Therefore, investigating microbialites is crucial to studying biological evolution.

The macro-characteristics of microbialites from the middle Ordovician Majiagou formation in Liujiang Basin are described in this work. The forming process and significance of microbialites on the ecological environment can be further discussed when the micro-characteristics are explored further. 


\section{Conclusions}

The main sedimentary rocks at the bottom member of Majiagou formation are characterized by chert-bearing strip, small amount of horizontal beddings and relatively complete fossils, the lower by bioclasts such as crinoid stems, the middle by calcarenitegravel, and the upper by fine-crystalline limestone and dolomite. The lithology features indicate that the sedimentary hydrodynamic environment had changed from weak to strong and then gradually weak again.

The main microbialites found in the middle Ordovician Majiagou formation in Liujiang Basin are microbial carbonate rocks, including wavy-shaped stromatolite carbonate rocks, columnar-shaped stromatolite carbonate rocks, cone-shaped stromatolite carbonate rocks, and oncolite carbonate rocks. They were developed at the bottom, lower, middle and upper member of Majiagou formation. Such a typical and complete microbial carbonate assemblage has rarely been observed in the Ordovician strata in Liujiang Basin and even in the northern part of North China.

The microbial carbonate rocks of middle Ordovician Majiagou formation in Liujiang Basin had outstanding features, rich types and regular evolution process. The further and detailed research for the significance of the microbial carbonate rocks in sedimentary environment, hydrodynamic conditions, ecological environment, energy minerals, and paleontological evolution is still necessary.

\section{Acknowledgements}

This research was financially supported by open fund of Shandong Key Laboratory of Depositional Mineralization \& Sedimentary Mineral (No. DMSM20190027), National Natural Science Foundation of China (No. 41802016), National and Provincial Tops Undergraduate Courses "Sedimentary Rock Petrology", Postgraduate Demonstration Course Construction Project of Hebei, China (No. KCJSX2021092), Provincial and University Educational Reform Project (2020GJJG589, 2020J03), and Science and Technology Project of Hebei Education Department (BJ2018028).

\section{References}

[1] Kalkowsky E (1908) Oolith und stromatolith in Norddeutschen Buntsandstein. Deutsche Geologischen Gesellschaft Zeitschrift 60: 68-125

[2] Aitken JD (1967) Classification and environmental significance of cryptalgallimestones and dolomites, with illustrations from the Cambrian and Ordovician of southwestern Alberta. Journal of Sedimentary Petrology 37 (4): 1163-1178.

[3] Flügel E, Kiessling W (2002) Patterns of Phanerozoic reef crises. In: Kiessling W, Flügel E, Golonka J (eds) Phanerozoic Reef Patterns. SEPM Special Publication 72, pp 691-733.

[4] Burne RV, Moore LS (1987) Microbialite: organosedimentary deposits of benthic microbial communities. Palaios 2 (3):
$241-254$.

[5] Liang YZ, Zhu SX, Gao ZJ, Du RL, Qiu SY (1995) New progress in the study of stratomalites- microbialite. Regional Geology of China 1:57-65, 43.

[6] Dai MY, Qi YA, Chang YG, Wang M, Li D (2014) Oncoids and their significance from the second member of the Mantou formation (Cambrian Series 3), Dengfeng area, Henan. ActaSedimentologica Sinica 32 (3): 410-417. (in Chinese)

[7] Mei MX (2007) Revised classification of microbial carbonates: Complementing the classification of limestones. Earth Science Frontiers 14 (5): 222-234 (in Chinese)

[8] Luo P, Wang S, Li PW, Song JM, Jin YF, Wang GQ, Yang SS (2013) Review and prospectives of microbial carbonate reservoirs. ActaSedimentologicaSinica 31 (5): 807-823.

[9] Warusavitharana C, Parcell WC (2013) Sedimentary features, occurrence and cyclicity of microbialitefacies in the Roubidoux and Jefferson City formations of Missouri and Kansas. AAPG Bulletin 97 (11): 1849-1870.

[10] Wu YS, Jiang HX, Yu GL, Liu LJ (2018) Conceptions of microbialites and origin of the Permian-Triassic boundary microbialites from Laolongdong, Chongqing, China. Journal of Palaeogeography, 20 (5): 737-775 (in Chinese)

[11] Zhao GS (2011) Meso-proterozoicmicobialites from North China platform and their paleo-ceaographic significance. Dissertation, China University of Geosciences, Beijing.

[12] Yang XQ, Li Z (2018) Research progress in sedimentology of microbial carbonate rocks: A review based on the 33rd International Sedimentological Congress. ActaSedimentologicaSinica 36 (4): 639-650. (in Chinese)

[13] Riding R (2000) Microbial carbonates: the geological record of calcified bacterial-algal mats and biofilms. Sedimentology 47 (s1): 179-214.

[14] Wu YS, Jiang HX, Yang W, Fan JS (2007) Microbialite of anoxic condition from Permian-Triassic transition in Guizhou, China. Science in China: Series D 50 (7): 1040-1051.

[15] Riding R, Liang LY (2005) Geobiology of microbial carbonates: Metazoan and seawater saturation state influences on secular trends during the Phanerozoic. Palaeogeography, Palaeoclimatology, Palaeoecology 219 (1-2): 101-115.

[16] Shi XY, Zhang CH, Jiang GQ, Liu J, Wang Y, Liu DB (2008) Microbial mats in the Mesoproterozoic carbonates of the North China platform and their potential for hydrocarbon-ceneration. Geoscience 22 (5): 669-682 (in Chinese)

[17] Dupraz C, Reid RP, Braissant O, Decho AW, Norman, RS, Visscher PT (2009) Processes of carbonate precipitation in modern microbial mats. Earth-Science Reviews 96 (3): 141-162.

[18] Zhang LW, Hong TQ, Jia ZH (2011) Microbialites and its significances fromthe lower Triassic Helongshan formation in Chaohu area, Anhui Province, south China. Chinese Journal of Geology 46 (2): 392-403

[19] Alshuaibi A, Duane MJ, Mahmoud H (2012) Microbial-activated sediment traps associated with oncolite formation along a peritidal beach, Northern Arabian (Persian) Gulf, Kuwait. Geomicrobiology Journal 29 (8): 679-696. 
[20] Chang YG, Huang HZ, Zheng W, Sun FY (2013) Sedimentary characteristics of microbialites of the North China type in mantou formation Cambrian, Henan. Journal of University of Mining \& Technology 42 (2): 236-242

[21] Zhang WH, Shi XY, Tang DJ, Jiang GQ (2014) Oncolites from lower-middle Cambrian transition of the Western North China Platform: A study of their ultra-fabrics and biomineralization. Geoscience 28 (1): 1-15.

[22] Michal R, Grzegorz R (2016) Microbialites in the shallow-water marine environments of the Holy Cross Mountains (Poland) in the aftermath of the Frasnian-Famennian biotic crisis. Global and Planetary Change 136 (1): 30-40.

[23] Harwood CL, Sumner DY (2011) Microbialites of the Neoproterozoic Beck Spring Dolomite, Southern California. Sedimentology 58 (6): 1648-1673

[24] Whalen MT, Day J, Eberli GP, Homewood PW (2002) Microbial carbonates as indicators of environmental change and biotic crises in carbonate systems: Examples from the Late Devonian, Alberta basin, Canada. Palaeogeography, Palaeoclimatology, Palaeoecology 181 (1-3): 127-151.

[25] Wang YB, Tong JN, Wang JS, Zhou XG (2005a) Calcimicrobialite after end-Permian mass extinction in South China and its palaeoenvironmental significance. Chinese Science Bulletin 50 (7): 665-671.

[26] Wang YB, Tong JN, Wang JS, Zhou XG (2005b) Calcimicrobialites and its palaeoencironmental significance after Late-Permian mass extinction in South China. Chinese Science Bulletin 50 (6): 552-558. (in Chinese)

[27] Kershaw S, Crasquin S, Li Y, Collin PY, Forel MB, Mu X, Baud A, Wang YB, Xie SC, Maurer F, Guo L (2011) Microbialites and global environmental change across the Permian-Triassic boundary: A synthesis. Geobiology 10 (1): $25-47$.

[28] Fischer AG, Arthur MA (1977) Secular variations in the pelagic realm. In: Cook HE, Enos $\mathrm{P}$ (eds) Deep-water carbonate environments. SEPM Special Pulication 25, pp $19-51$

[29] Bottjer DJ, Campbell KA, Schubert JK, Droser ML (1995) Palaeoecological models, non-uniformitarianism, and tracking the changing ecology of the past. Geological Society 83: 7-26.

[30] Wood R (2000) Novel paleoecology of a postextinction reef: Famennian (Late Devonian) of the Canning basin, northwestern Australia. Geology 28 (11): 987-990.

[31] Wang Y, Shen JW, Yang HQ, Wang X, Liu MM (2011) Microbial carbonates and its research significance. Advances in Earth Science 26 (10): 1038-1049. (in Chinese)

[32] Feng SH, Li H, Jiang JJ, Lei Y, Niu YZ, Yang R, Liu YJ (2017) The Multiple Dolomitizations in Ordovician Majiagou Carbonate Rocks in Liujiang Basin, Qinhuangdao Area, North
China. ActaSedimentologicaSinica 35 (4): 664-680. (in Chinese)

[33] Liu SY, Cui YG (2015) Study and establishment of Liangjiashan standard stratigraphic section in Liujiang Basin. Heilongjiang technical information 26: 95-96. (in Chinese)

[34] Liu CZ, Ma FR (2016) Guidance book of geological practice in Beidaihe area. Petroleum Industry Press, Beijing

[35] Zhao G, Tan XC, Xiao JD, Lian CB (2016) Lithostratigraphic composition and one-dimensional digital description of lower Ordovician Liangjiashan formation in Liujiang Basin. Earth Science 41 (5): 873-875. (in Chinese)

[36] Gong EP, Han SH, Guan GY (1995) Evolution and sedimentary environment of algal bioherms from middle to upper Cambrian in Liujiang Basin, Hebei. ActaSedimentologicaSinica 13 (1): 75-81. (in Chinese)

[37] Semikhatov MA, Raaben ME (1996) Dynamics of the global diversity of Proterozoic stromatolites; Article 2, Africa, Australia, North America, and general synthesis. Stratigraphy and Geological Correlation 4 (1): 492-513

[38] Semikhatov MA, Raaben ME (2000) Proterozoic stromatolate taxonomy and biostratigraphy. In: Riding RE, Awramik SM (eds) Microbial Sediments. Springer-Verlag, Heidelberg, pp 295-306

[39] Chang YG, Zheng W (2012) Stromatolites: progress and problems. Sedimentary Geology and Tethyan Geology 32 (2): 89-93. (in Chinese)

[40] Chang YG, Qi YA, Zheng W, Wang M, Dai MY (2013) Research progress on microbial mat ecosystem of stromatolites. Journal of Henan Polytechnic University (Natural Science) 32 (3): 356-364. (in Chinese)

[41] Heim A (1916) Monographie der Churfrsten-Mattstock-Gruppe (3 Teil). BeitrGeolKarteSchweiz NF 20, pp 369-573

[42] Bian LZ, Huang ZC (1988) On classification and paleoecological significance of oncolite and featrures of non-skeletal oncolite in Ordovician, An Hui, China. ActaPaleontologicaSinica 27 (5): 544-552, PlateI-V. (in Chinese)

[43] Yang RC, Fan AP, Han ZZ, Chi NJ (2011) Status and Prospect of Studies on Oncoid. Advances in Earth Science 26 (5): 465-474 (in Chinese)

[44] Logan BW, Rezak R, Ginsburg RN (1964) Classification and environmental significance of algal stromatolites. The Journal of Geology 72: 68-83.

[45] Wolf KH (1965) Petrogenesis and paleoenvironment of Devonian algal limestones of New South Wales. Sedimentology 4: 113-178.

[46] Peryt TM (1983) Oncoidsacomment to recent developments. In: Peryt TM (ed) Coated Grains. Springer Berlin Heideberg, New York, pp 273-275. 